\title{
ALAT PEWARNA BATIK ROL GANDA (PEDER)
}

\author{
Taufiq Hidayat $^{1}$, Kunto Hamijoyo ${ }^{2}$ \\ ${ }^{1}$ Universitas Nahdlatul Ulama Surakarta, ${ }^{2}$ AT-AUB Surakarta \\ ${ }^{1}$ viqdmangan@yahoo.co.id, ${ }^{2}$ kuntoaub@gmail.com
}

\begin{abstract}
One of the commodities of the creative industry in Indonesia, which until now is still superior, is the batik industry, both batik screen printing batik, stamp and printing. The stages of the production process of stamp batik are the process of tasting, coloring, drying and drying / drying. Problems that arise during the production process in batik UKM Pandanwangi is a coloring process that takes longer and is wasteful of the dye. The existence of a dye or dye tool is needed, a tool that is able to provide a solution to this problem is a peder. The purpose of implementing the partnership program for the community (PKM) is to help provide solutions specifically the problem of the production process. The method developed is a survey of UKM, designing tools, carrying out discussions with partners in relation to the results of tool design, tool manufacturing processes, component performance testing, work testing of tools and production processes. The results of the program are a peder with specifications: size of $157 \mathrm{~cm} \times 149 \mathrm{~cm} \times 144$ $\mathrm{cm}$, source of $0.5 \mathrm{Hp}$ electric motor power, transmission (V-belt, pulleys, chains and gears), dye tanks, pressing (2 rollers and fasteners). The speed of the production process for the program results is $15 \mathrm{~m}$ per minute. The conclusion of the implementation of the PKM program is that SME partners are able to carry out the coloring / dyeing production process on average \pm 2000 m every day.
\end{abstract}

\section{Keywords: stamp batik, coloring, peder}

Abstraksi. Salah satu komoditas industri kreatif di Indonesia yang sampai saat ini masih menjadi unggulan adalah industri batik, baik batik sablon batik tulis, cap dan printing. Tahapan proses produksi batik cap adalah proses pengecapan, proses pewarnaan, pelorotan dan pengeringan/penjemuran. Persoalan yang muncul saat proses produksi di UKM batik Pandanwangi adalah proses pewarnaan yang membutuhkan waktu lebih lama dan boros cairan pewarnanya. Keberadaan alat pewarna atau celup sangat dibutuhkan, alat yang mampu memberikan solusi permasalahan ini adalah alat peder. Tujuan dari pelaksanaan program kemitraan bagi masyarakat (PKM) adalah membantu memberikan solusi khususnya persoalan proses produksi. Metode yang diterapkembangkan adalah survey ke UKM, mendesain alat, pelaksanaan diskusi dengan mitra hubungannya dengan hasil desain alat, proses pembuatan alat, uji kinerja komponen, uji kerja alat dan proses produksi. Hasil dari pelaksanaan program adalah sebuah alat peder dengan specifikasi: ukuran alat $157 \mathrm{~cm} \times 149 \mathrm{~cm} \times 144 \mathrm{~cm}$, sumber tenaga motor listrik $0.5 \mathrm{Hp}$, transmisi ( Vbelt, puli, rantai dan gear), bak pewarna, pressing (2 rol dan pengencang). Kecepatan proses produksi peder hasil program adalah $15 \mathrm{~m}$ per menitnya. Kesimpulan dari pelaksanaan program PKM adalah UKM mitra mampu melakukan proses produksi pewarnaan/pencelupan rata rata $\pm 2000 \mathrm{~m}$ per hari.

Kata kunci: batik cap, pewarnaan, peder

\section{PENDAHULUAN}

Batik adalah kain bergambar yang pembuatannya dilakukan secara khusus yaitu dengan menuliskan/menempelkan cairan lilin dengan alat bantu yang berupa canting atau cap. Batik Indonesia, merupakan sebuah karya seni yang menggabungkan teknik, teknologi, dan motif yang disesuaikan budaya lokal. Keberadaan batik telah di tetapkan 
UNESCO sebagai warisan budaya (Masterpieces of the Oral and Intangible Heritage of Humanity) sejak 2 Oktober 2009 [4]. Ditinjau dari etimologi, kata batik berasal dari bahasa Jawa, ambhatik dari kata amba berarti lebar, luas, kain dan titik. Titik atau matik (kata kerja dalam bahasa Jawa yang berarti membuat titik) dan kemudian berkembang menjadi istilah batik. Jadi batik dapat diartikan menghubungkan titik-titik menjadi gambar tertentu pada kain yang luas atau lebar. Batik juga mempunyai pengertian segala sesuatu yang berhubungan dengan membuat titiktitik tertentu pada kain mori. Batik berasal kata bathik, mengacu pada huruf Jawa tha yang menunjukan bahwa batik adalah rangkaian dari titik-titik yang membentuk gambaran tertentu. Batik sangat identik dengan suatu teknik (proses) dari mulai penggambaran motif hingga pelorotan. Salah satu ciri khas batik adalah cara penggambaran motif pada kain yang menggunakan proses pemalaman, yaitu menggoreskan malam (lilin) yang ditempatkan pada wadah yang bernama canting atau cap. Menurut KRT. DR. HC. Kalinggo Hanggopuro (2002, 1-2), dalam buku Bathik sebagai Busana Tatanan dan Tuntunan menuliskan bahwa para penulis terdahulu menggunakan istilah batik yang sebenarnya tidak ditulis dengan kata batik akan tetapi seharusnya Bathik. Hal ini mengacu pada huruf Jawa tha bukan ta dan pemakaiaan bathik sebagai rangkaian dari titik adalah kurang tepat atau dikatakan salah [4]. Batik merupakan sebuah karya budaya yang menjadi warisan nenek moyang dan memiliki nilai seni yang cukup tinggi, dengan motif atau corak, serta tata warna yang khas sesuai asal batik yang menunjukkan budaya bangsa Indonesia. Batik sebagai aset budaya merupakan ikon produk Indonesia yang memiliki nilai historis dan memiliki citra ekslusif yang menggambarkan status pemakainya [2].

Berdasarkan data Kementerian Perindustrian, pelaku usaha batik di Indonesia didominasi oleh industri kecil dan menengah (IKM) yang tersebar di 101 sentra. Jumlah tenaga kerja yang terserap di sentra IKM batik mencapai 15 ribu orang. Nilai ekspor kain batik dan produk batik pada tahun 2016 mencapai USD149,9 juta dengan pasar utama Jepang, Amerika Serikat, dan Eropa. Dalam mendukung pengembangan industri batik nasional, Dirjen IKM Kemenperin Gati Wibawaningsih mengemukakan, Ditjen IKM Kemenperin telah melakukan berbagai kegiatan strategis, antara lain program peningkatan kompetensi SDM, pengembangaan kualitas produk, standarisasi, fasilitasi mesin dan peralatan serta promosi dan pameran. Usaha-usaha resebut dimaksudkan untuk meningkatkan jumlah produk yang berkualitas dan mampu ekspor [1].

UKM Batik yang menjadi mitra dalam pelaksanaan program kemitraan bagi masyarakat (PKM) tahun angggaran 2018 adalah UKM Pandanwangi milik bapak Dwiyanto yang beralamat di Ngentak, Rt 1 Rw 1 Polokarto, Sukoharjo. Sebaran UKM-UKM batik terdapat di beberapa wilayah, Surakarta ada di Pasar Kliwon, Kauman dan Laweyan. Sukoharjo ada di Polokarto dan Mojolaban. Sragen ada di Kecamatan Masaran dan Kecamatan Plupuh. Desadesa yang merupakan sentra pengrajin batik di wilayah Kecamatan Masaran adalah Desa Kliwonan dan Desa Pilang, 
sedangkan yang berada di wilayah Kecamatan Plupuh antara lain di Desa Gedongan, Desa Jabung dan Desa Pungsari [7]. Hasil survey pada proses produksi di UKM mitra adalah permasalahan tingkat kenyamanan (nilai ergonomi) dan peralatan pendukung proses. Nilai ergonomi pada saat melakukan cap dan pewarnaan adalah pada postur tubuh, tangan, punggung dan leher. Kondisi punggung, leher dan tangan berada terlalu rendah sehingga tingkat kenyamanan dalam waktu lama dari jam 8.00 sampai dengan jam 16.00 WIB berdampak pada tingkat kelelahan dan konsentrasi kerja. Kondisi ini harus dicarikan solusi baik dengan solusi alat bantu atau membuat alat baru seperti peder. Hal ini juga disampaikan oleh Halim Mahfud dalam penelitiannya dengan tema analisis ergonomi pada proses pembuatan batik. Permasalahan utamanya adalah posisi punggung, leher terlalu menunduk dan tangan pada posisi yang sama dan terlalu melebar yang disebabkan oleh meja kerja dan proses pewarnaan terlalu tinggi dan melebar [5].

Perbaikan nilai ergonomi dan efisiensi pada alat perlu dilakukan. Beberapa peralatan pewarna kain batik yang sudah dikembangkan antara lain oleh Rosvita, mengembangkan peralatan celup yang berupa bak segitiga memanjang dengan ketinggian dari tanah $63 \mathrm{~cm}$ dan ada peralatan bantu untuk menarik hasil pencelupan [6]. Tingkat ergonomi sudah ada perbaikan akan tetapi peralatan tersebut sama saja dengan sebelumnya yaitu mempergunakan bak pencelup. Saat proses pewarnaan kain dengan panjang 30 yard misalnya akan sangat kesulitan (memposisikan kain 30 yard) dan proses penempatan hasil pewarnaan juga mengalami kesulitan. Fiky, melakukan penelitian dengan judul Pengembangan Detail Desain Alat Pencelupan di Workstation Pewarnaan di Rumah Batik Komar. Hasil dari penelitiannya dapat disimpulkan penggunaan alat pewarna non manual jauh lebih sempurna hasilnya. Specifikasi dari alat ini adalah Rangka Kain berbentuk lingkaran yang memiliki dua belas jari-jari yang berguna untuk mempertahankan bentuk kain menjadi lingkaran. Diameter lingkaran rangka kincir sebesar $80 \mathrm{~cm}$ dengan jarak antara kedua lingkaran $100 \mathrm{~cm}$. Ukuran Part lainya mengacu pada ukuran part rangka kain. Rangka bak menggunakan besi UNP berukuran $50 \mathrm{~mm}$ x $38 \mathrm{~mm}$ dengan tujuan dapat mengimbangi ekstetika dari kincir yang berdiamter 80 $\mathrm{cm}$. Selain dari pertimbangan ekstetika pemilihan material juga dilihat dari kemudahan di bentuk untuk mendekati bentuk dari konsep yang dipilih. Sumber penggerak bergantung dari kekuatan tenaga manusia [3]. Kelemahan dari alat ini adalah campur tangan manusia masih cukup tinggi dan vital (sumber penggerak), perlu adanya persiapan untuk rol kain di rol yang ada di alat dan tidak ada peralatan yang dipasang untuk mengurangi kandungan air di kain.

Berdasarkan dari pengembangan pengembangan alat pewarna yang sudah ada dan dilihat dari sudut ergonomi saat proses pembuatan batik khususnya proses pewarnaan atau pencelupan maka perlu ada pengembangan dan pengadaan peralatan celup di UKM mitra yang berupa alat peder. Alat peder ini keunggulannya adalah bahan kain batik tidak perlu dikondisikan dalam rol, tenaga penggerak dengan motor listrik minimal $0.5 \mathrm{hp}$, waktu proses cukup singkat $300 \mathrm{~m}$ per 20 menit dan tingkat 
kebasahan kain pasca pencelupan sangat rendah karena adanya pressing kain.

\section{METODE PENELITIAN}

Guna penyelasaian pelaksanaan program PKM tahun 2018, maka tim membuat alur pelaksanaan program.

Tabel 1. Alur penyelesaian program

\begin{tabular}{rrr}
\hline No & \multicolumn{2}{c}{ Tahapan Pelaksanaan } \\
\hline $1 \quad$ Tahapan awal pelaksanaan, yaitu: \\
- & Survey \\
& - & Diskusi dengan pihak \\
& UKM \\
& - & Pembuatan gambar kerja \\
- & Inventaris alat \\
- & Pembelian bahan/ alat \\
- & Final gambar kerja \\
\hline 2 Tahapan pembuatan alat, yaitu: & Pembuatan rangka utama \\
- & Pembuatan rol utama (cor \\
& dan pembubutan) \\
- & Pembuatan rol penarik \\
& (belakang) \\
- & Setting sumber tenaga \\
- & Pembuatan dan setting \\
& bak pewarna \\
- & Setting rol utama dan rol \\
& penarik \\
- & Setting transmisi \\
\hline &
\end{tabular}

3 Tahapan uji kinerja komponen alat, yaitu:

- Pergerakan komponen komponen (putaran, keselarasan dan kebisingan)

- Pergerakan kain batik cap

- Kecepatan pergerakan kain batik cap

5 Tahapan uji skala UKM

(Uji coba proses pewarnaan oleh UKM), yaitu:

- Kecepatan

proses pewarnaan

- Tingkat kering kain (hubungannya dengan pressing rol utama)

- Kepasitas proses pewarnaan kain batik

6 Tahapan perbaikan pasca uji coba skala UKM, yaitu:

- Pengecekan sumber penggerak

- Pengecekan transmisi

- Pengecekan pressing rol utama

- Pengecekan kekencangan baut 


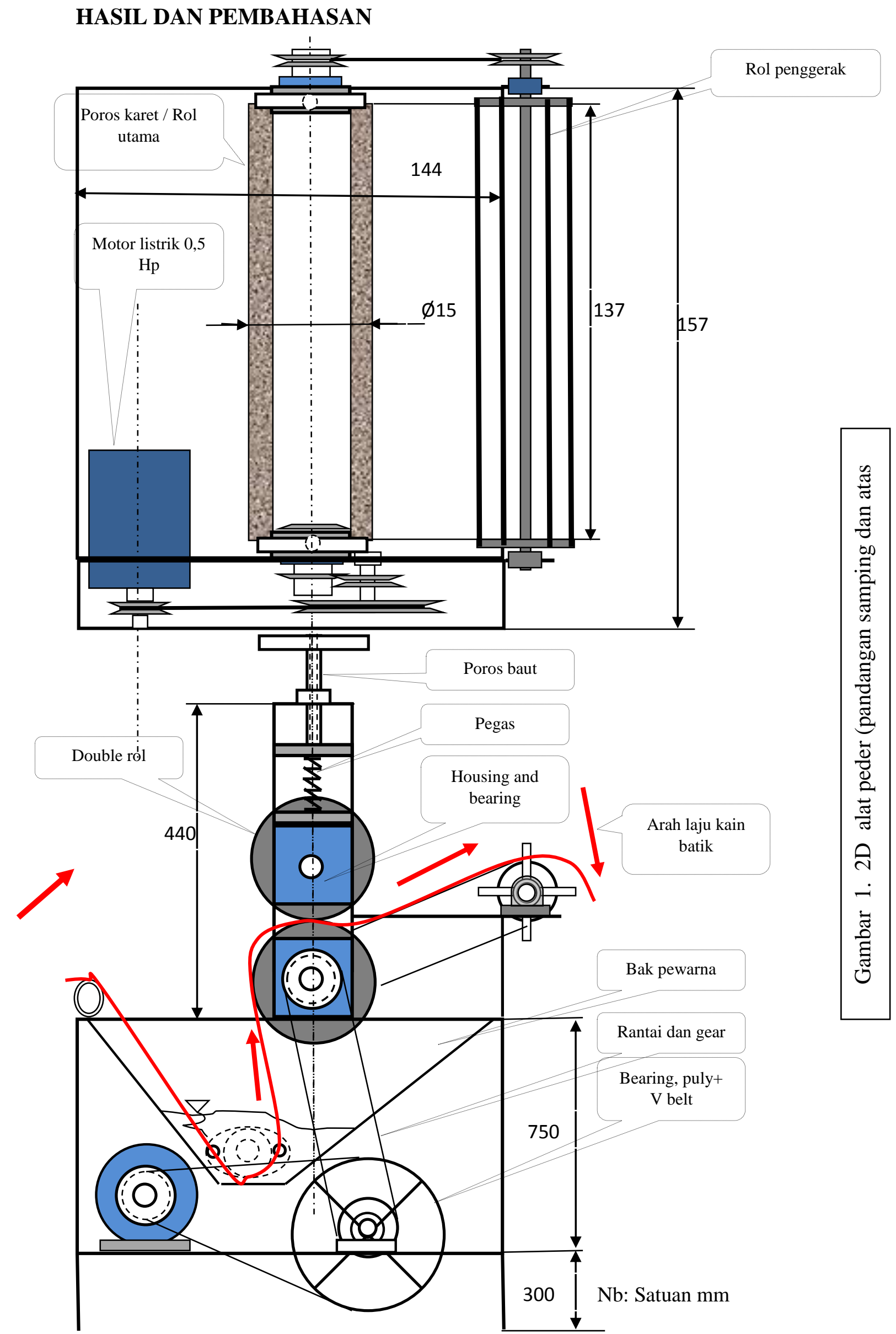


Untuk lebih memberikan gambaran hasil program yang jelas, dapat dilihat pada gambar hasil dokumentasi pelaksanaan program
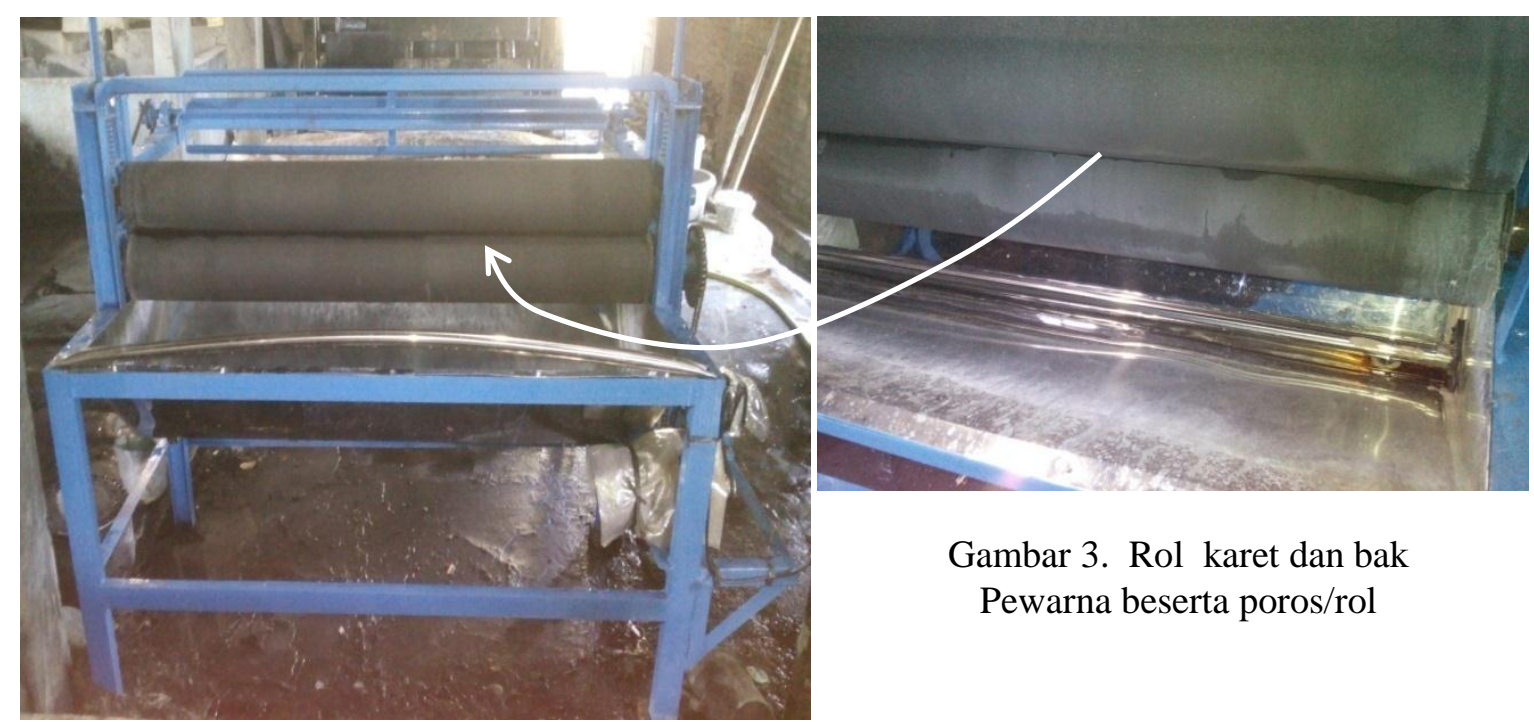

Gambar 3. Rol karet dan bak Pewarna beserta poros/rol

Gambar 2. Alat pewarna (peder) tampak depan

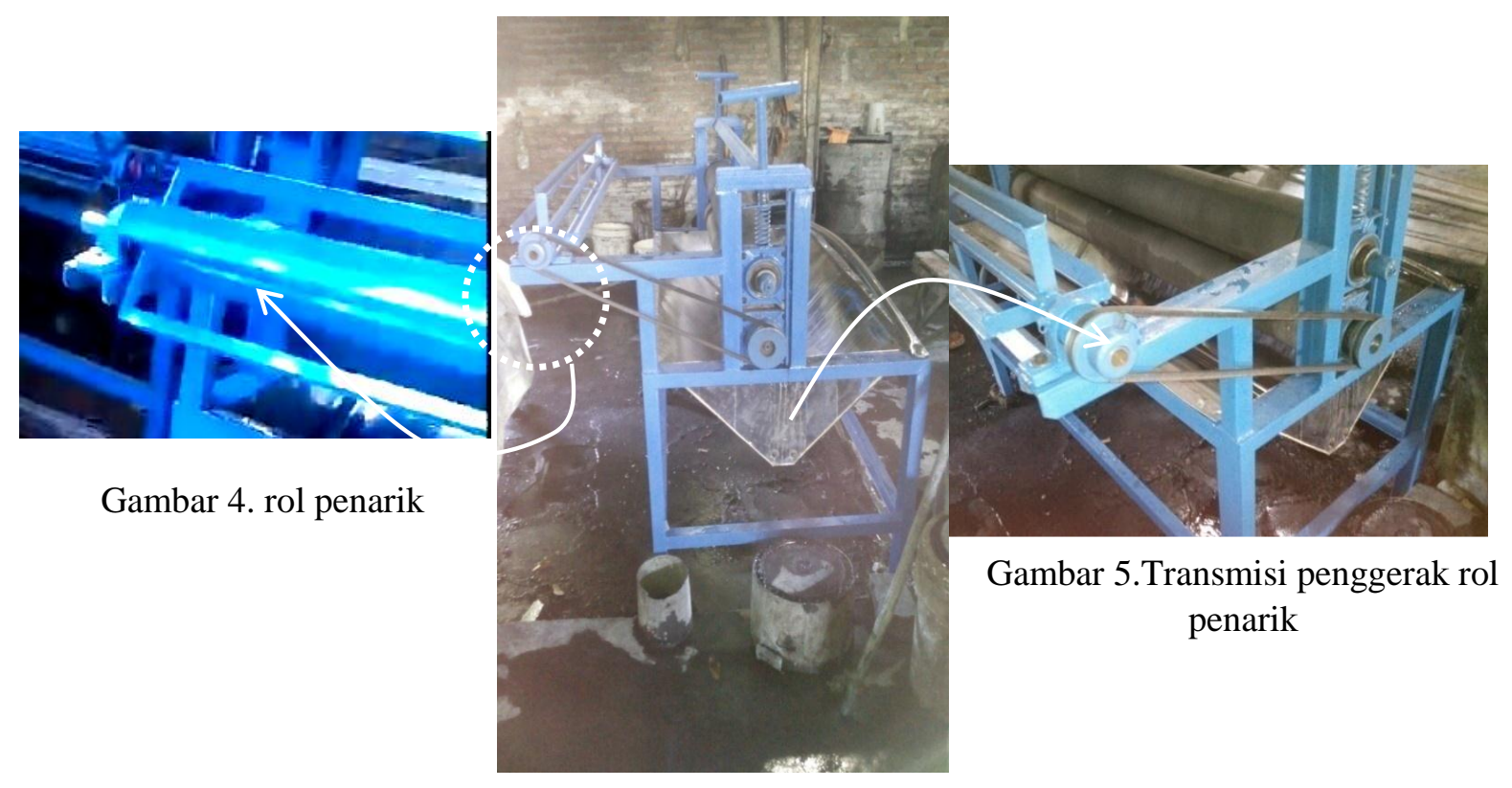

Gambar 6. Pandangan samping 
Tabel 2. Specifikasi alat pender:

\begin{tabular}{|c|c|c|c|}
\hline No & Komponen & Bahan & $\begin{array}{l}\text { Ukuran } \\
\text { (mm) }\end{array}$ \\
\hline \multirow{4}{*}{1} & \multirow{4}{*}{ Rangka } & $\begin{array}{c}\text { Specifikasi } \\
\text { utama }\end{array}$ & $\begin{array}{c}(1570 \times 1450 \\
\times 1440)\end{array}$ \\
\hline & & Besi U & $(70 \times 50)$ \\
\hline & & besi $\mathrm{L}$ & $\begin{array}{c}(70 \times 50) \text { dan } \\
(30 \times 30)\end{array}$ \\
\hline & & $\begin{array}{c}\text { Pipa } \\
\text { stainless } \\
\text { Steel }\end{array}$ & $\varnothing 50$ \\
\hline \multirow[t]{2}{*}{2} & \multirow[t]{2}{*}{ Rol utama } & $\begin{array}{c}\text { Poros besi } \\
\text { pejal dan cor } \\
\text { karet }\end{array}$ & $(\varnothing 15 \times 1370)$ \\
\hline & & $\begin{array}{c}\text { Bearing+hou } \\
\text { sing }\end{array}$ & $(130 \times 130)$ \\
\hline \multirow[t]{3}{*}{3} & \multirow{3}{*}{$\begin{array}{c}\text { Rol } \\
\text { penarik }\end{array}$} & $\begin{array}{c}\text { Specifikasi } \\
\text { utama }\end{array}$ & $(\varnothing 170 \times 1540)$ \\
\hline & & Besi L & $30 \times 30$ \\
\hline & & Bearing & \\
\hline \multirow{3}{*}{4} & \multirow{3}{*}{ Penggerak } & Motor listrik & $\begin{array}{c}0.5 \mathrm{hp} / 3600 \\
\mathrm{rpm}\end{array}$ \\
\hline & & $\begin{array}{l}\text { Puly V-belt } \\
\text { dan puly } \\
\text { kecil }\end{array}$ & $\varnothing 350$ dan Ø80 \\
\hline & & Gear+rantai & 170 dan 50 \\
\hline 5 & $\begin{array}{c}\text { Bak } \\
\text { pewarna }\end{array}$ & $\begin{array}{l}\text { Stainless } \\
\text { steel }\end{array}$ & $\begin{array}{c}1440 \times 1570 \times \\
550\end{array}$ \\
\hline
\end{tabular}

Komponen komponen yang ada di peder adalah:

1. Penggerak

Penggerak mempergunakan motor listrik $0.5 \mathrm{hp} / 0.37 \mathrm{kw} / 1400 \mathrm{rpm}$. Kecepatan putaran rol dan kecepatan tarikan kain batik dapat dinaikkan dengan mengganti motor listrik dengan hp yang lebih besar. Tidak ada setting ulang apabila ingin mengganti motor listrik.

2. Rol utama

Rol utama adalah berfungsi untuk menarik sekaligus pressing kain basah agar kain menjadi lebih kering (kadar air dalam kain berkurang).

Rol utama ini dibuat dengan besi pejal yang kemudian dicor dengan karet sintetis. Hasil pengecoran dilakukan proses pembubutan agar supaya tingkat kerataan dan kehalusan permukaan karet sama. Perubahan bentuk permukaan karet akan berdampak pada berkurangnya daya cengkram dan pressing terhadap permukaan kain. Kain tidak sempurna dalam proses pergerakannya dan tingkat keringnya pun sangat kecil.

Pengaturan tingkat kekencangan pressing rol antar permukaan di atur dengan pergerakan poros baut dan pegas.

3. Rol belakang (penarik)

Fungsi dari komponen ini adalah untuk membantu pergerakan kain.

Pergerakan rol ini digerakkan oleh poros utama dengan bantuan puli dan V-belt. Kecepatan antara rol belakang dengan poros rol utama $1: 1$.

4. Bak pewarna

Fungsi dari komponen ini adalah sebagai tempat untuk menampung cairan pewarna.

Bak pewarna tidak dikondisikan untuk dipanasi saat proses pewarnaan.

Bahan pewarna: reaktif (kuning pakai yellow fg, oranye pakai 03R, merah pakai red $\mathrm{Rb}$, biru pake turkish blue G, hijau campuran turkish sama fg.

Komposisi bahan pewarna yaitu satu liter air dicampur dengan \pm 40 gram bubuk pewarna.

1 liter air dan 40 gram pewarna bisa dipergunakan untuk mewarnai panjang kain 7 meter.

Dikarenakan tidak mempergunakan proses pemanasan pada cairan pewarna maka dikondisikan dengan pemberian campuran soda kostik sama water glass (pengunci) 
Perbandingan proses pewarnaan manual dengan mempergunakan peder adalah sebagai berikut:

Manual,

a. Jumlah kain yang mampu diwarna dalam satu harinya hanya mampu mencapai 500 - 750 meter per harinya.

b. Penggunaa bahan pewarna lebih boros, 1 liter air +40 gram pewarna untuk panjang kain \pm 4 meter.

c. Kerugian pada b akan menyebabkan perhitungan biaya permeternya menjadi bertambah menjadi Rp 1250

d. Membutuhkan tenaga yang sudah terampil dalam proses pewarnaan. Sering terjadi belang pada kain apabila tenaga pewarnanya belum terampil.

e. Proses untuh menekan kadar air dalam kain dilakukan dengan manual yaitu dengan memeras kain (memuntir kain). Tenaga manusia khususnya kekuatan tangan sangat vital. Kondisi ini akan menyebabkan proses pewarnaan akan lebih lama.

f. Kecepatan proses pewarnaan menuju siap jemur per kain jarik ( \pm 2 meter) membutuhkan lama proses \pm 5-7 menit.

Apabila peralatan peder khususnya dua rol yang tidak presisi (permukaannya sudah tidak rata) akan menyebabkan:

1. 1 liter air +40 gram pewarna hanya mampu dipergunakan untuk mewarnai kain \pm 5 meter.

2. Kandungan air dalam kain yang masih tinggi berpengaruh pada lama proses pengeringannya.

Peder hasil PKM,

1. Jumlah kain yang diwarna dalam satu harinya mampu mencapai \pm 2000 meter perharinya.
2. Penggunaan bahan pewarna, 1 liter air + 40 gram pewarna mampu mewarnai kain menjadi 7 meter.

3. Ongkos perwarnaan kain permeter adalah Rp. 1000

4. Proses pewarnaan akan terhidar dari permasalahan belang. Kain masuk ke bak pewarna pada posisi melebar sesuai lebar kain yang dibantu dengan rol yang berada di dasar bak pewarna.

5. Kadar air dalam kain akan sangat rendah hal ini dikarenakan kain menerima pressing dengan melalui diantara dua rol yang tingkat pressingnya diatur oleh pegas dan mur-baut.

6. Kecepatan pewarnaan dengan peder mampu mencapai 300 meter per 20 menit.

Prinsip kerja dari peder dalam proses pewarnaan atau pencelupan adalah:

1. Meracik cairan pewarna dan memasukka ke bak pewarna

2. Meletakkan kain batik yang akan diwarna.

3. Menarik ujung kain (diperlihatkan pada gambar 1)

4. Mengatur tekanan rol utama dengan memutar baut penyetel.

5. Menghidupkan motor listrik. Jumlah pekerja yang terlibat dari proses pewarnaan ini berjumlah dua orang, satu menjaga kain masuk (input) dan satu orang menata dan merapikan kain hasil pewarnaan atau pencelupan.

\section{SIMPULAN}

Hasil dari pemanfaatan pemakaian peder di UKM mitra adalah:

1. Kapasitas proses pewarnaan di UKM mitra lebih cepat, per menit mampu 
mewarnai kain batik cap dengan panjang $15 \mathrm{~m}$. tenaga motor listrik menjadi $1 \mathrm{hp}$ atau lebih.

2. Kecepatan proses pewarnaan mampu ditingkatkan dengan menaikkan

\section{DAFTAR PUSTAKA}

Disperindag Jateng (2017, Juni). Pewarna Alam Batik Kurangi Impor Sintetik. Disperinda.jetengprov.go.id/portal/page/berita/pewarna-alam-batik-kurangiimpor-sintetik.

Dyah Encus Ayoe moerniwati (2013). Studi Batik Tulis. jurnal .fkip.uns.ac.id/index.php/senirupa/article/view/1211/813.9 Juni 2017

Fiky RiyanDarmawan Pratama1, Rino Andias Anugraha2, Teddy Sjafrizal (2015). Development Of The Detail Design Dyeing Tools In ColoringWorkstation At Rumah Batik Komar. e-Proceeding of Engineering : Vol.2, No.2 Agustus 2015 | Page 4495. ISSN : 2355-9365.

https://id.m.wikipedia.org/wiki/Batik

Mahwud, H., Santy, Nurfajriyah (2014). Analisis Ergonomi Pada Proses Pembuatan Batik Di Sentra Batik Bogor Tradisiku. Bina Teknika, Volume 10 No 1, Edisi Juni 2014, 10-18.

Rosvita Febrina Daranindra (2010). Perancangan Alat Bantu Proses Pencelupan Zat Warna dan Penguncian Warna Pada Kain Batik Sebagai Usaha Mengurangi Interaksi Dengan Zat Kimia Dan Memperbaiki Postur Kerja. Skripsi 2010. Jurusan Teknik industri Fakultas Teknik Universitas Sebelas Maret.

Supriyadi, Slamet dan Sariyatun.2011. Pemberdayaan Perempuan Pengrajin Batik "Girli" Untuk Meningkatkan Perekonomian Keluarga Dan Mengembangkan Desa Wisata Di Kabupaten Sragen. Laporan Penelitian Hasil Hibah. Surakarta: Universitas Sebelas Maret. 